\title{
Antiparasitic Activity of Single Solanum ferox Extract and Concoction with Zingiber zerumbet and Boesenbergia pandurata Extracts to Control Argulus sp. on Goldfish (Cyprinus carpio)
}

Esti Handayani Hardi ${ }^{1,2}$, Rudi Agung Nugroho ${ }^{2,3}$, Irawan Wijaya Kusuma ${ }^{2,4}$, Gina Saptiani ${ }^{1,2}$, Agustina $^{1}$, Abinawanto ${ }^{5}$, Yushinta Fujaya ${ }^{6}$, Bambang murtiyoso ${ }^{7}$, Tjahjo Winanto ${ }^{8}$, Nurhidayat $^{9}$

${ }^{1}$ Microbiology Laboratory of Fisheries and Marine Sciences, Department of Aquaculture, Fisheries and Marine Sciences, Mulawarman University, Indonesia.

${ }^{2}$ Research Centre of Medicine and Cosmetics in Tropical Rainforest Resources, PUI-PT OKTAL, Mulawarman University, Samarinda, Indonesia

${ }^{3}$ Department of Biology, Faculty of Mathematics and Natural Sciences, Mulawarman University, Samarinda, East Kalimantan, Indonesia.

${ }^{4}$ Faculty of Forestry, Mulawarman University, Samarinda, East Kalimantan, Indonesia.

${ }^{5}$ Departement of Biology FMIPA, Universitas Indonesia.

${ }^{6}$ Faculty of Marine Science and Fishery, Hasanuddin University, Makassar, Indonesia.

${ }^{7}$ Politeknik AUP, Jakarta

${ }^{8}$ Faculty of Fisheries and Marine Science Jenderal Soedirman University

${ }^{9}$ Research Ornamental Fish Culture, KKP, Indonesia

Abstract: Argulus is an ectoparasite that frequently infects goldfish, with severe effects and a high death rate. The use of plant extracts has been widely reported to have antiparasitic activities, including one of the solasodine compounds in sour eggplant extracts. This research evaluated the antiparasitic activities of Compositions A (Solanum ferox and Zingiber zerumbet extract at 400 and 200 ppm, respectively), B (SFE and Boesenbergia pandurata at 900 ppm), and C (single Solanum ferox at 400 ppm). The research stages comprised 1) isolation and analysis of solasodine content in sour eggplant extracts and its extract composition, 2) in vitro antiparasitic activities on Argulus sp. at doses of 50 and 100 ppm with a testing time of 60-240 minutes, and 3) in vivo antiparasitic activities on Argulus sp. on goldfish at a dose of $100 \mathrm{ppm}$ and observation for 2-12 hours of medication. The results showed that sour eggplant extracts had a solasodine concentration of $7.151 \mathrm{mg} / \mathrm{L}$, whereas the derivative compositions $\mathrm{A}, \mathrm{B}$, and C were 656, 485, and 295 ppm, respectively. The in vitro testing demonstrated that composition A was effective for killing approximately $80-100 \%$ of Argulus, whereas compositions B and C killed $80-90 \%$ and $60-70 \%$, respectively. Viewed from the effectiveness for killing parasites, the result was excellent (above 50\%). The in vivo medication test was continued using three extract compositions at a dose of $100 \mathrm{ppm}$. Compositions $\mathrm{A}, \mathrm{B}$, and $\mathrm{C}$ were found to be capable of releasing $81.33,75.67$, and 71.00 arguli, respectively, per fish. We concluded 
that the single SFE extract and a concoction with BPE and ZZE had reasonable antiparasitic activity, whereas the concoction of SFE and ZZE killed more Argulus parasites at a higher rate.

Keywords: Argulus sp., antiparasitic, natural product, fish diseases, solasodine, Solanum ferox.

\section{Introduction}

Argulus japonicus was found first in Asia to infect goldfish (Carassius auratus) and koi fish (Cyprinus carpio). It has also been reported in the United States of America, particularly in Florida, Georgia, Louisiana, California, Hawaii, Illinois, Maryland, Washington, and Wisconsin [1]. The expanding infection has been caused by the transportation of koi fish, as the carrier of Argulus sp., although this fish might be infected by other pathogens, namely bacteria, fungi, and parasites [2].

According to Steckler and Yanong [3], Argulus sp. belongs to the Branchiura parasite and has an oval shape, covered by a wide carapace, sunken on the adhesive side, and convex on the other. Argulus sp. has two compound eyes, and its body has a suction disc that makes it is difficult to clean with water, although it can be removed with abrasion. Forcibly removing the parasite results in a wound on the fish skin because Argulus has a venom gland on its stylet that is used for penetrating the skin, transferring venom into the blood and body liquids. It causes skin irritation and visible inflammation, namely redness and wound on the infected skin [4-6]. The Argulus sp. parasite is frequently found in freshwater fish, sea fish, crab, lobster, and shrimp. There are almost 100 Argulus species worldwide, infecting several hosts [3].

The A. japonicus parasite, infecting the caudal and anal fins, is found on the body surface, whereas operculum is also found in the gills of goldfish (Carassius auratus). Argulus in fish can cause bleeding, wounds, and ulcers, and the formed wound can be a location for pathogens (Aeromoniasis, Pseudomoniasis) to penetrate [7]. Furthermore, according to Lamarre and Cochran [8], fish infected with Argulus show abnormalities in behavior, including irritation, color change, listlessness, anorexia, and anemia because the pre-oral stylet that stabs the fish skin has a cytolytic toxin that causes damage to blood cells, mucus, and epithelial cells, softening the fish and allowing Argulus to more easily consume it.

The death rate in infected fish is relatively high. Therefore, this organism causes considerable loss in both small and large fish. To solve the issue of Argulus sp., many farmers use chemicals, such as sodium chloride ${ }^{9}$ and trichlorfon at $0.25 \mathrm{ppm}$ [7]. However, antibiotic or chemical use can cause irritation on fish skin, and side effects associated with the use of 
chemicals on the environment are frequently reported [10]. Although the utilization of chemicals on decorative fish is allowed, their continuous use negatively affects fish health.

The use of natural materials for hampering and curing infected fish has been widely reported [11-15]. Extract of garlic (Allium sativum) is capable of killing trichodinids [16], theronts, and tomonts from the Ichthyophthirius multifiliis parasite [17]. Ekanem et al. [18] used extracts from Mucuna pruriens and Carica papaya to kill the free-swimming parasite, $I$. multifiliis. One of the potential antiparasitic plants is sour eggplant, which contains solasodine, a steroidal glycoalkaloid compound. Some studies have shown that solasodine has antifungal $[19,20]$, antibacterial $[21-24,47,48]$, anticancer $[25,26,45,46]$, and antiparasitic potencies as well as several other important activities [27].

This article discusses the detection of solasodine compounds in the extracts of sour eggplant and the use of single Solanum ferox (SFE) extract and a concoction with Boesenbergia pandurata (BPE) and Zingiber zerumbet (ZZE) extracts to kill and release Argulus sp. that infects goldfish (C. carpio). These three extracts have been widely found to have antibacterial effects against Aeromonas hydrophila, Pseudomonas fluorescens, Vibrio harveyi, and V. haemolytic [28-36,47,48]. Various contents (e.g., alkaloids, flavonoids, solasodine, zerumbet, and panduratin) are secondary metabolic materials in these three extracts capable of negatively affecting pathogens (e.g., bacteria, fungi, protozoa, crustacea, nematodes).

The first case of the Argulus parasite was reported in the Mahkota fish pond, Sungai Kapih Street, Sambutan District, Samarinda City, East Kalimantan on the $20^{\text {th }}$ of February 2021. The owner of this fish pond contacted the Laboratory of Aquaculture Microbiology and Biotechnology, Faculty of Fishery and Marine Sciences on the $24^{\text {th }}$ of February 2021. Observations regarding fish death since the $20^{\text {th }}$ of February 2021 showed that 20 of 130 goldfish in the pond died; it was reported later that 102 fish died.

After the reporting, the medication process was initiated using SFE, BPE, and ZZE in single and mixed extracts with the immersion method. The medication process is further described in the next chapter.

\section{Results}

2.1. ANALYSIS OF SOLASODINE CONTENT IN Solanum ferox EXTRACTS AND ITS extracts composition.

\section{A. Solasodine Calibration Curve}


A solasodine calibration curve was made as a reference for determining the solasodine level in SFE and the composition of the produced extract. The calibration curve was constructed using a high-performance liquid chromatography (HPLC) instrument with a standard compound concentration of solasodine at 120-600 ppm, resulting in a curve with equation $\mathrm{y}=0.0004+0.2702$ (Figure 1 . fr) and correlation coefficient 0.9724 . HPLC analysis showed a peak of solasodine retained at 2.379 minutes.

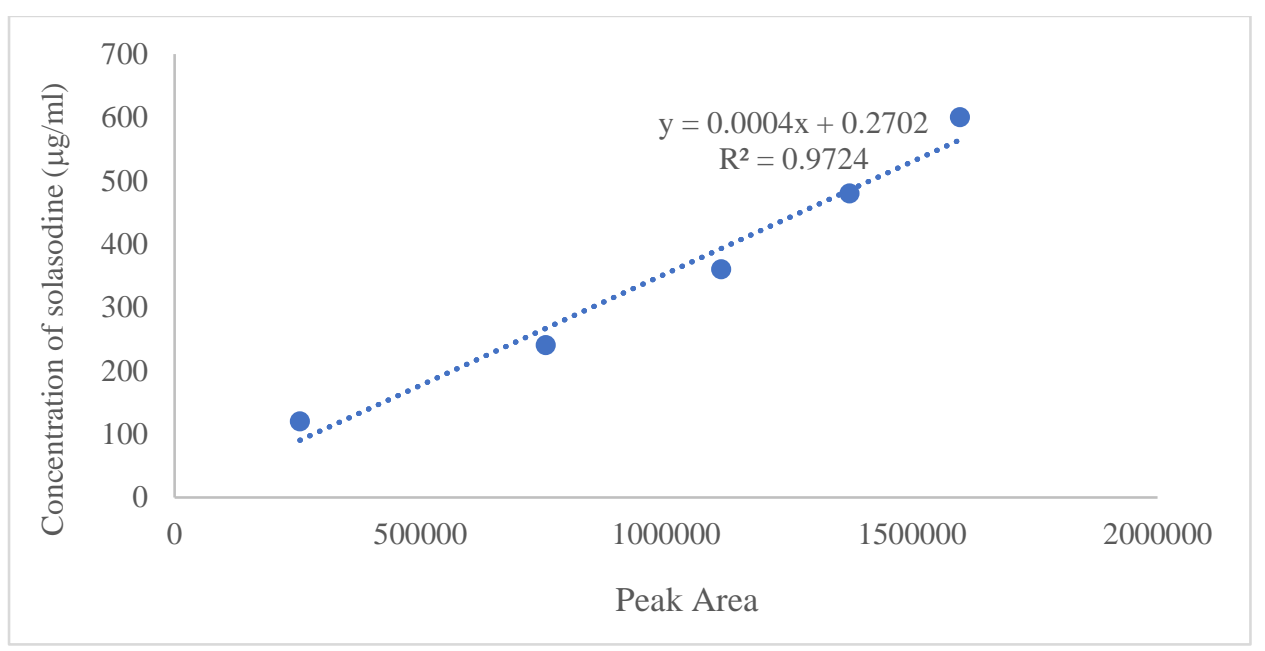

Figure 1. Standard Calibration curve of $\underline{s}$ ranging from 120 to $600 \mu \mathrm{g} / \mathrm{ml}$ in mobile phase.

\section{B. Analysis of solasodine content in sour eggplant extracts}

Analysis of solasodine content in S. ferox fruit extract using High-Performance Liquid Chromatography (HPLC) were discussed in this section. The presence of solasodine were analyzed based on the extracts obtained from $S$. ferox fruit collected from two extraction period (coded with SFE 1 and SFE 2).

HPLC analysis on SFE 1 and SFE 2 were presented in Fig 2. HPLC chromatogram showed at least 12 peaks at retention time ranged from 2.212 to 9.650 minutes. Peak at 2.212 min was identified as solasodine referred to the HPLC analysis of the standard solasodine. 


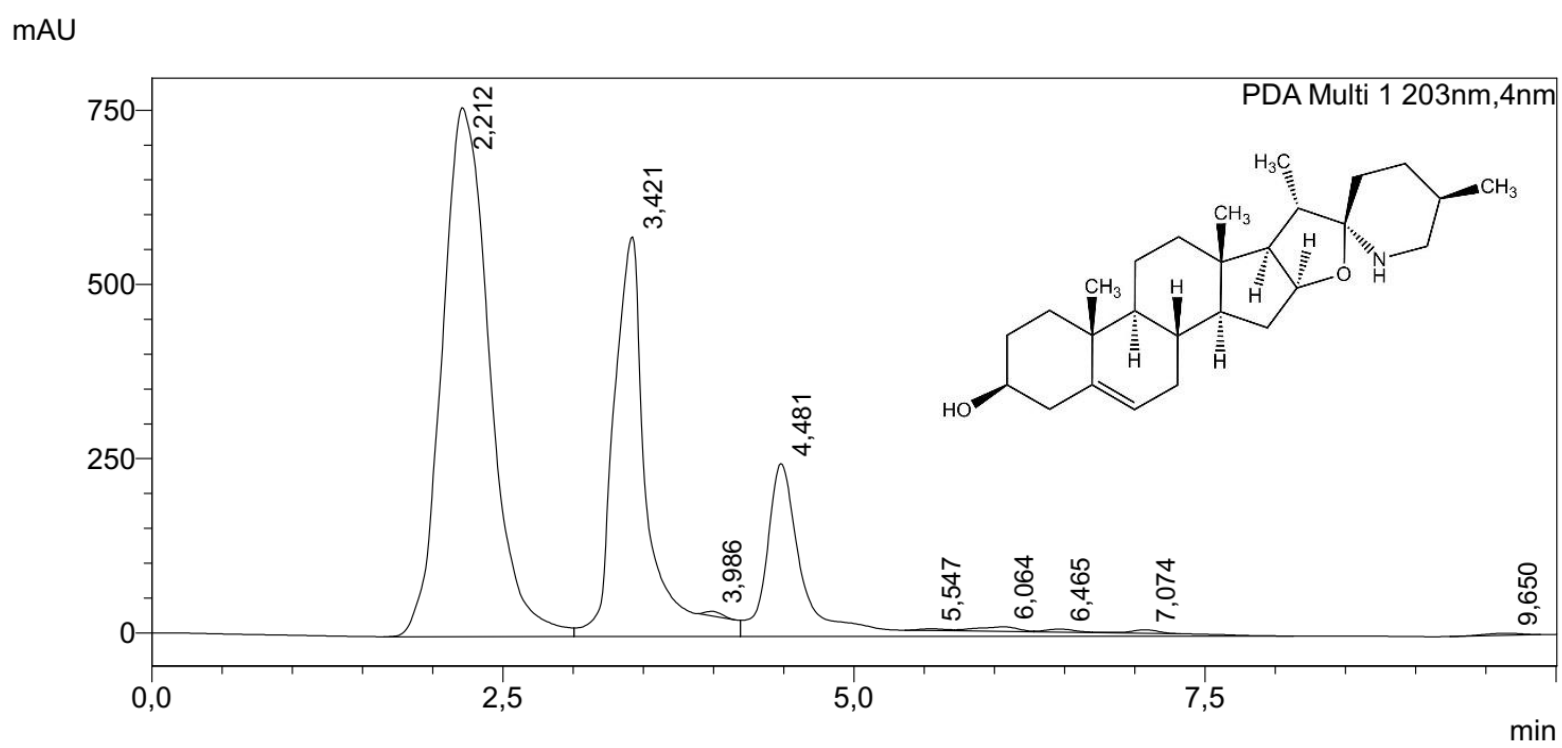

mAU

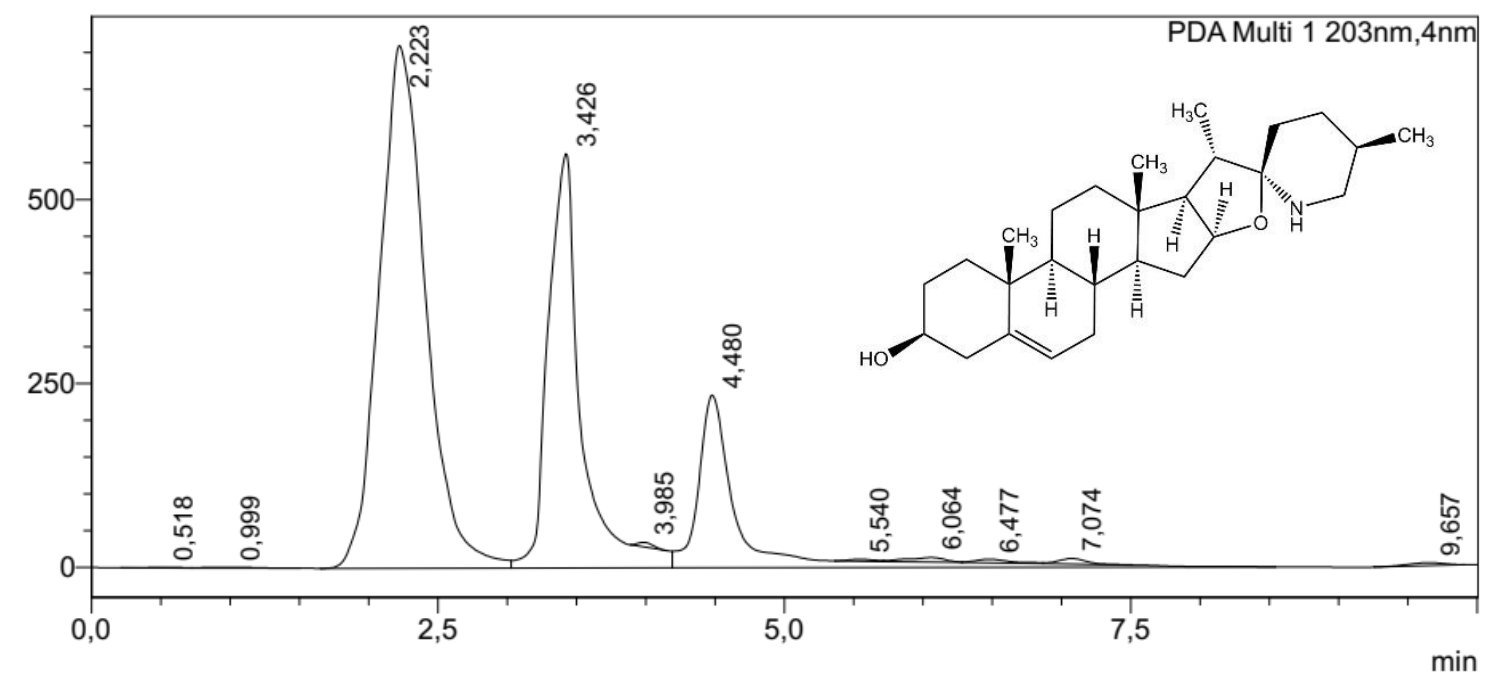

Figure 2. HPLC chromatogram of SFE 1 (above, $t_{R} 2.212 \mathrm{~min}$ ) and SFE 2 (below, $t_{R} 2.223$ min) showing the occurrence of solasodine in sour eggplant extract.

The HPLC chromatogram showed the width of area for the peak at 2.212 minutes (the peak for solasodine) was $17,877,468$. Based on the standard calibration curve of solasodine, solasodine content in SFE 1 was determined $7,151 \mu \mathrm{g} / \mathrm{ml}$ from the basis of $10,000 \mu \mathrm{g} / \mathrm{ml}$ of injected volume in HPLC analysis..

The HPLC analysis of eggplant extract from the extraction period 2 was presented in Fig 2. The HPLC chromatogram showed at least 11 peaks at retention times 0.518 to 9.657 minutes. The peak at 2.223 minutes was confirmed as solasodine by with reference to the HPLC analysis to that of standard solasodine. The HPLC chromatogram showed the width of area for the solasodine peak identified at 2.223 min was $16,594,359$. The standard calibration curve 
suggested the solasodine content was $6,638 \mu \mathrm{g} / \mathrm{ml}$ based on the $10,000 \mu \mathrm{g} / \mathrm{ml}$ of sample volume used in HPLC analysis..

\section{Analysis of solasodine content in Composition A (SFE and ZZE)}

The S. ferox extracts were used as main ingredients of the products composition coded with products A1 and A2. HPLC analysis of product composition A1 was shown in Fig 3. The HPLC chromatogram showed at least 11 peaks at retention times of 0.906 to 9.725 minutes. Solasodine presence in product composition A1 was indicated by the peak at $2.239 \mathrm{~min}$.

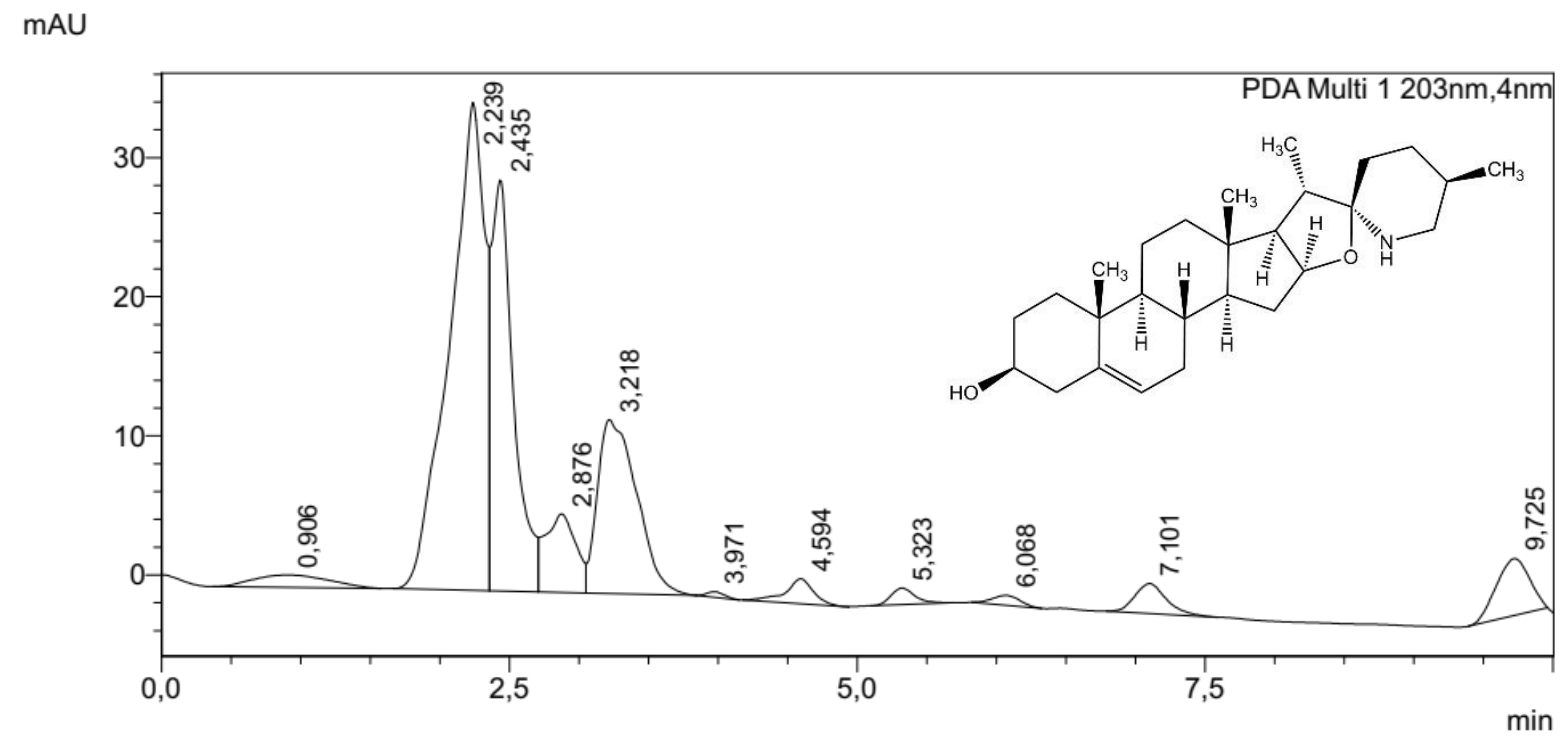

mAU

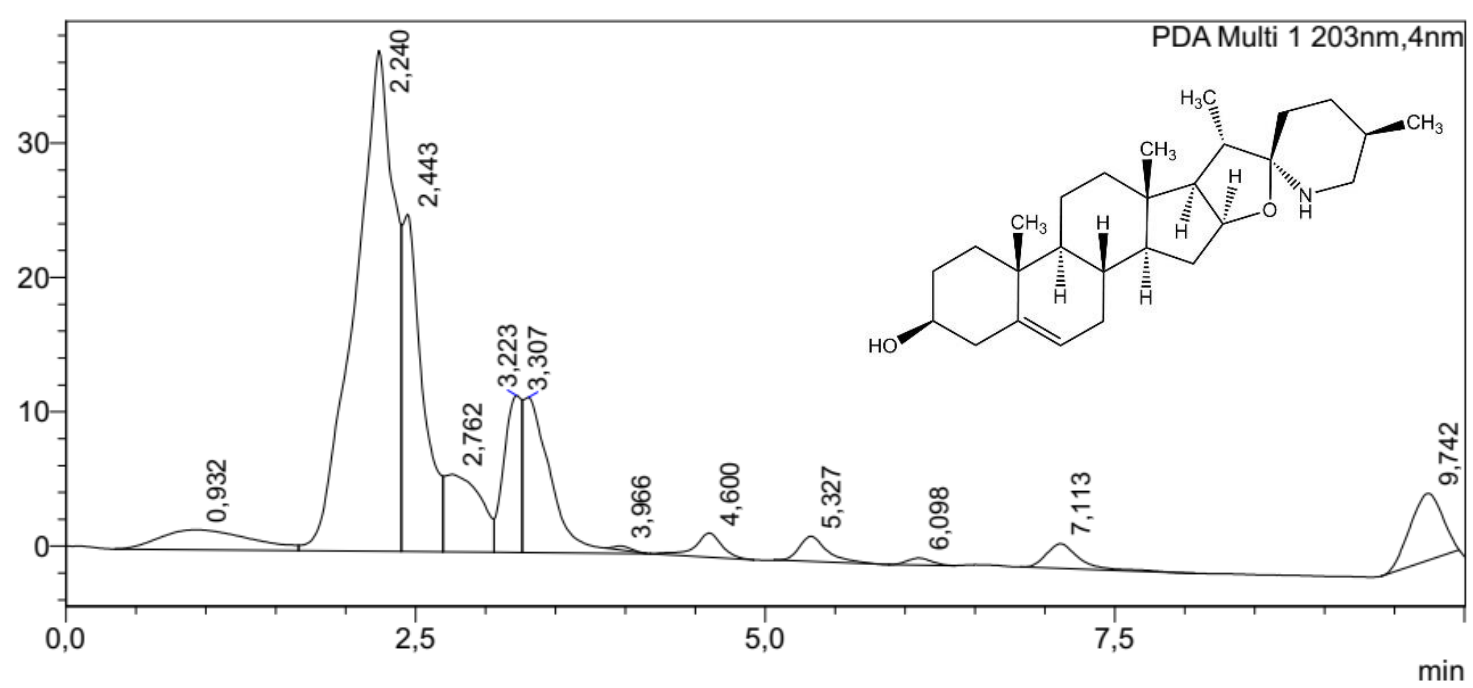

Figure 2. HPLC chromatogram of products A1 (above, $t_{R} 2.239 \mathrm{~min}$ ) and A2 (below, $t_{R}$ $2.240 \mathrm{~min}$ ) showing the occurrence of solasodine in sour eggplant extract 
The HPLC chromatogram showed a peak 2.239 min that is identified as solasodine with the width of area was 622,008 . Based on the solasodine calibration curve, the solasodine content in the product A1 was calculated as much as $248 \mu \mathrm{g} / \mathrm{ml}$.

Furthermore, solasodine content in product composition A2 done by an HPLC analysis was given in Fig 3. HPLC chromatogram provided at least 12 peaks at the retention times 0.932-9.742 min. A peak observed at $2.240 \mathrm{~min}$ was determined as solasodine with reference to the standard solasodine analysis.

The HPLC chromatogram showed the width of area for the solasodine peak at 2.240 min was 736,862 . The solasodine concentration in product A2 based on the equation in the solasodine calibration curve (Figure 1) was calculated to be $295 \mu \mathrm{g} / \mathrm{ml}$.

\section{Analysis of solasodine content in composition B (SFE and BPE)}

Other products with the main ingredients of S. ferox extracts were product composition B and coded with product B1 and B2. The HPLC analysis of product B1 was shown in Fig 4. The HPLC chromatogram showed at least 12 peaks from 0.384 to $9.620 \mathrm{~min}$. Solasodine compound in product A was indicated by the occurrence a peak at $2.350 \mathrm{~min}$.

mAU

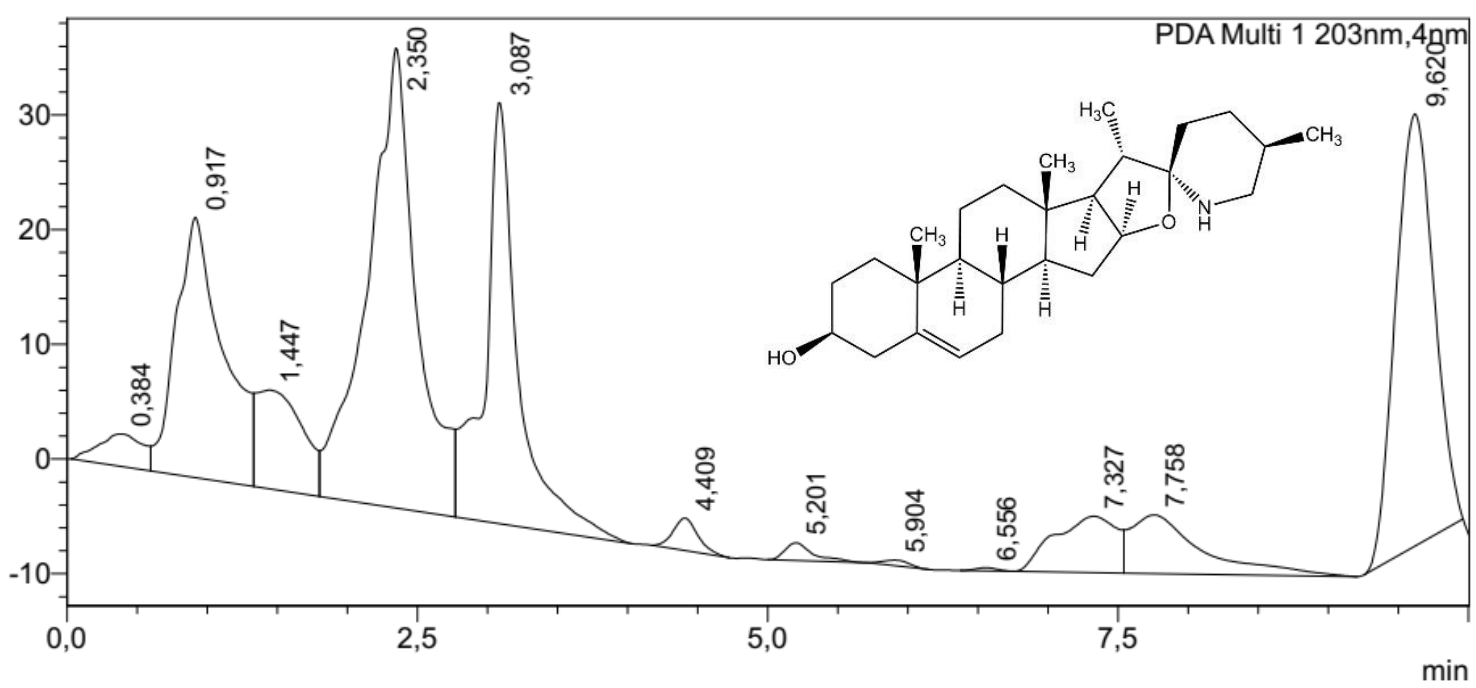




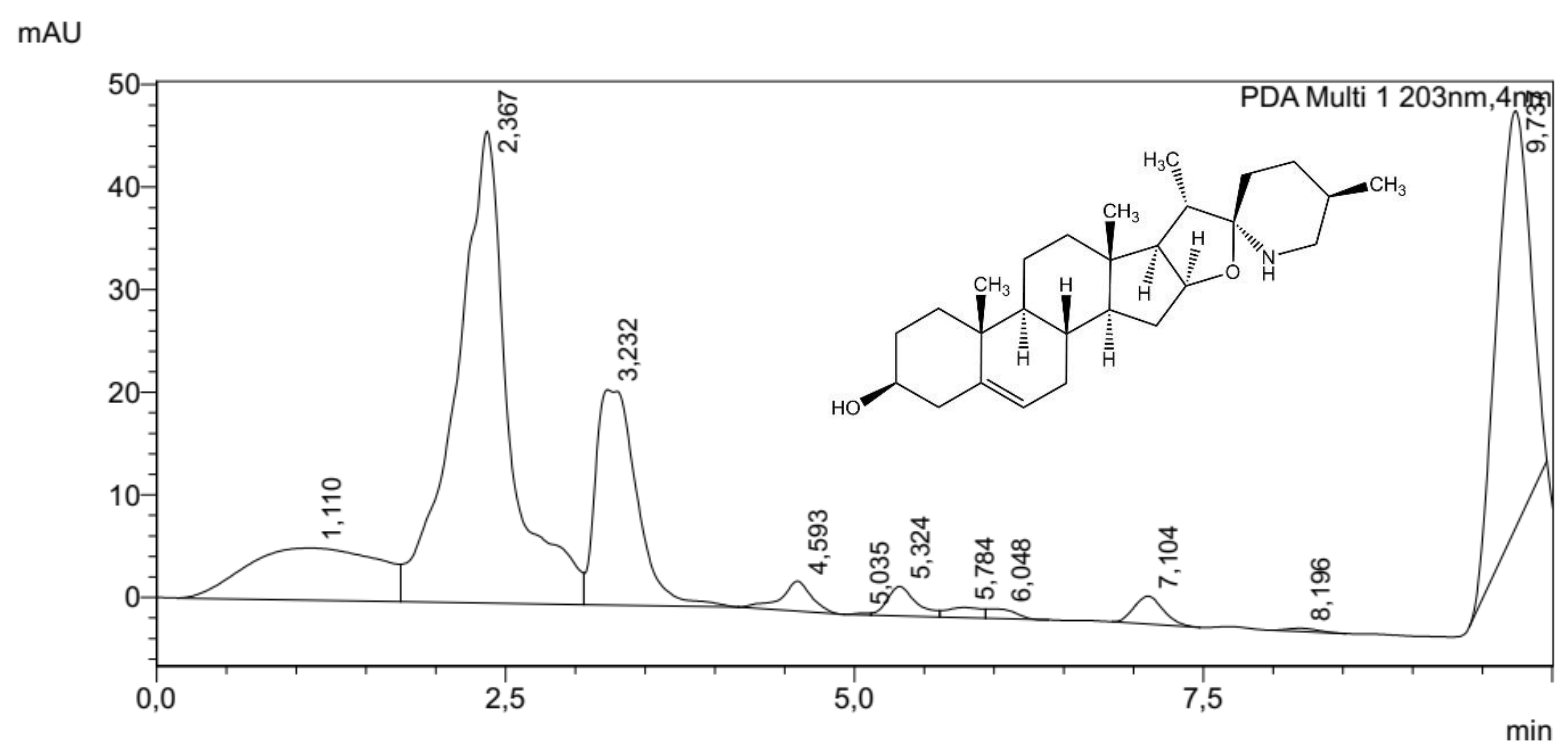

Figure 4. HPLC chromatogram of products B1 (above, $t_{R} 2.350 \mathrm{~min}$ ) and $\mathrm{B} 2$ (below, $\mathrm{t}_{\mathrm{R}}$ $2.367 \mathrm{~min}$ ) showing the occurrence of solasodine in sour eggplant products.

The HPLC chromatogram showed the width of area for the peak at $2.350 \mathrm{~min}$ for solasodine was 981,938). The solasodine content in product B1 was determined as much as $393 \mu \mathrm{g} / \mathrm{ml}$ based on the $10,000 \mu \mathrm{g} / \mathrm{ml}$ of injtected volume of the product.

Solasodine content in product B2 was analyzed by HPLC as shown in Figure 4. Eleven peaks were presenced with the retention times of 1.110 - 9.737 min. Solasodine occurence in product B2 were indicted by the peak appeared at $2.350 \mathrm{~min}$.

A peak at the retention time of 2.367 min having width area of 1,212,706 informed the presence of solasodine. Solasodine content in composition product B 2 was determined as high as $485 \mathrm{ppm}$ with the reference to that of solasodine standard calibration curve.

\section{E. Analysis of solasodine content in composition C (SFE)}

Different product composition of S. ferox extracts were prepared and coded as products $\mathrm{C} 1$ and $\mathrm{C} 2$. The HPLC analysis of product $\mathrm{C} 1$ was presened in Fig 5. More than 12 peakswith the retention from 0.975 to 9.740 min were detected at the chromatogram. 
mAU

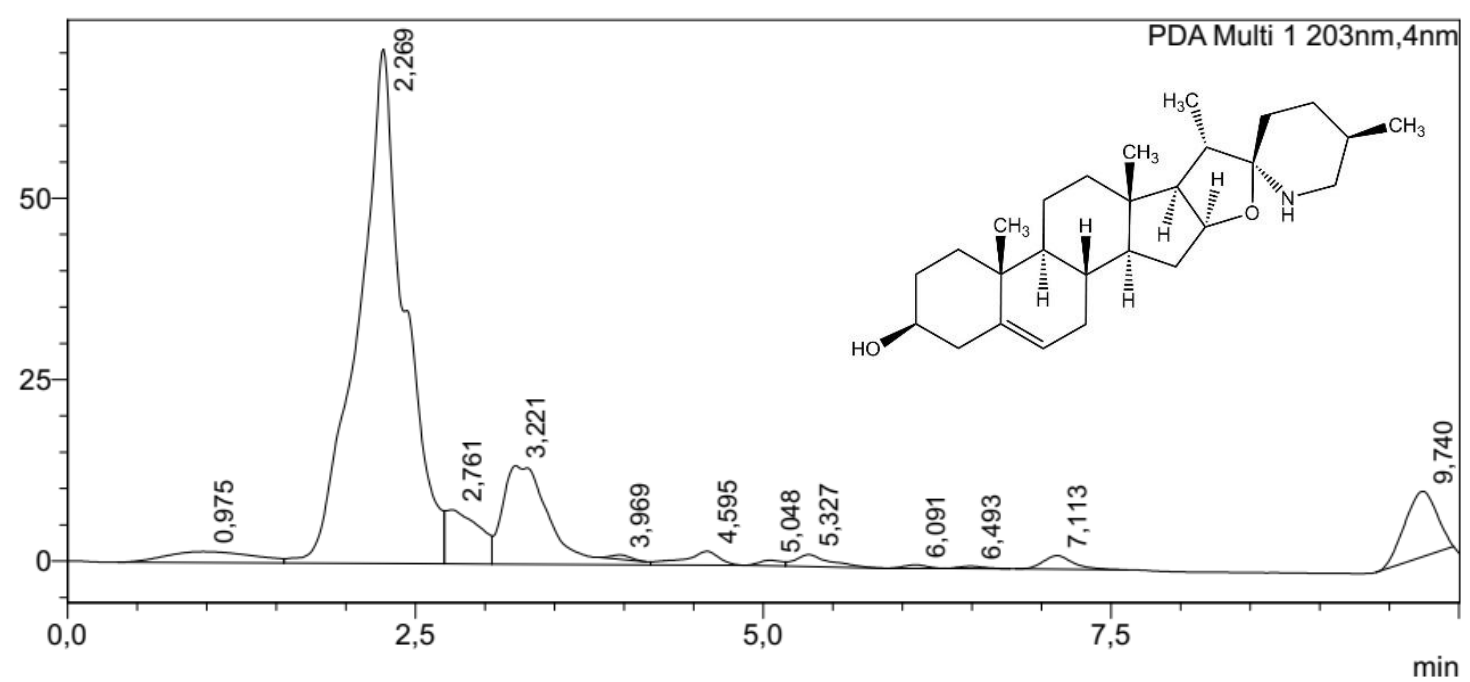

mAU

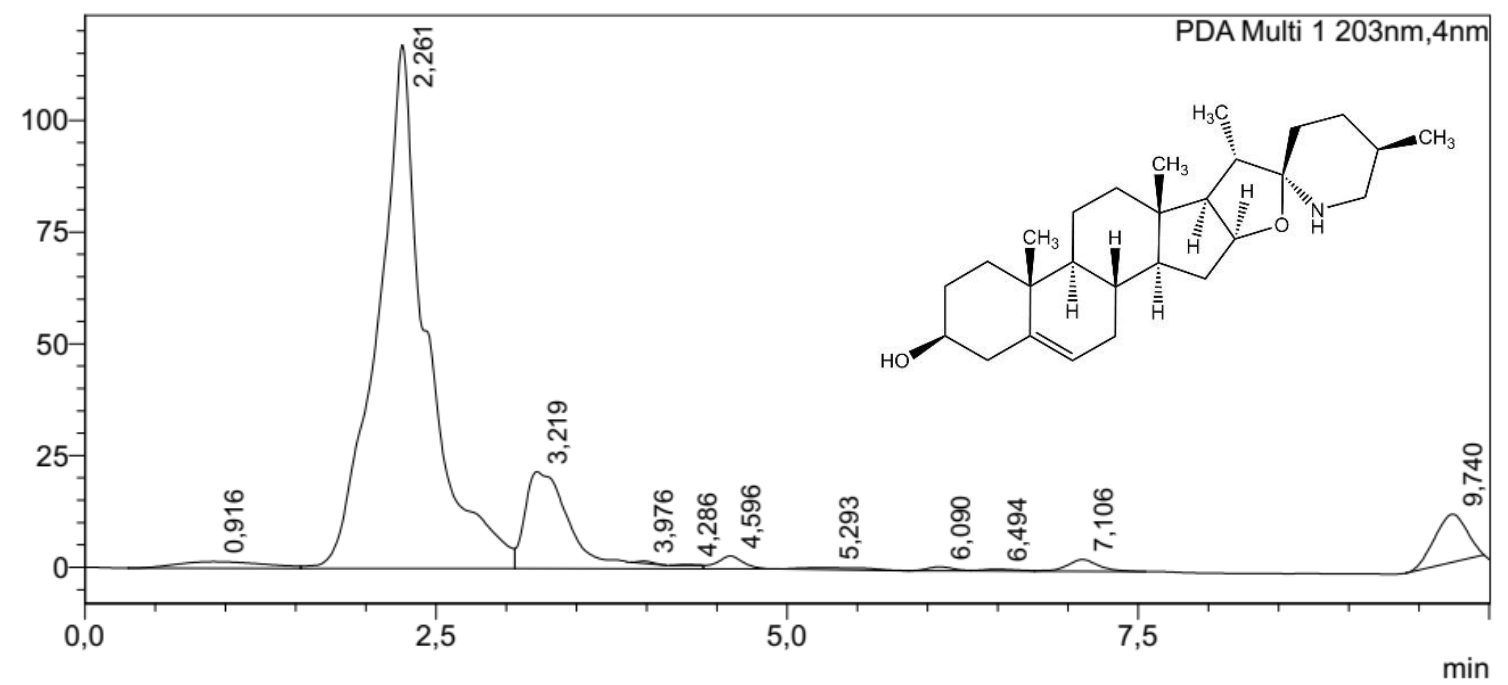

Figure 5. HPLC chromatogram of products $C 1$ (above, $t_{R} 2.269 \mathrm{~min}$ ) and $\mathrm{C} 2$ (below, $\mathrm{t}_{\mathrm{R}}$ $2.261 \mathrm{~min}$ ) showing the occurrence of solasodine in sour eggplant products

The presence of solasodine in product $\mathrm{C} 1$ was indicated by the peak at $2.269 \mathrm{~min}$ as presented in Fig 5. min.. A peak detected at the retention time of 2.269 min having width area of $1,640,862$ was used to calculate the solasodine content. The solasodine concentration in product $\mathrm{C} 1$ was determined to be $656 \mu \mathrm{g} / \mathrm{ml}$ based on the equation in the solasodine calibration curve (Figure 1).

Furthermore, analysis of solasodine content in product C2 done by HPLC was presented in Figure 5. The occurrence more than of 11 peaks at times having retention from 0.916 to 9.740 min were observed at the chromatogram.

The HPLC chromatogram showed the width of area for the peak at $2.261 \mathrm{~min}$ identified as solasodine was $2,857,078)$. Based on the standard calibration curve of solasodine, solasodine 
content in product $\mathrm{C} 2$ was calculated to be $1,142 \mu \mathrm{g} / \mathrm{ml}$ from the basis of $10,000 \mu \mathrm{g} / \mathrm{ml}$ of the injected product $\mathrm{C} 1$ sample.

\subsection{General description of goldfish infected by Argulus sp.}

The fish used in this research was goldfish infected by the Argulus sp. parasite, which was observed in the abdominal, pectoral, and caudal fins, and redness in the infected organ (Figure 10). Argulus sp. has a mouth with a stylet, which is used to inject a digestive enzyme into the fish body and to absorb food that becomes liquid. This digestion process causes severe irritation and tissue damage in the gill tissue or infected skin [7]. Goldfish infected by Argulus sp. in the fish pond of Samarinda, East Kalimantan had hemorrhagic red spots, lesions, nectrotic wounds, and ulceration (Figure 10); these findings agree with the results of Y1ldiz and Kumantas [37].
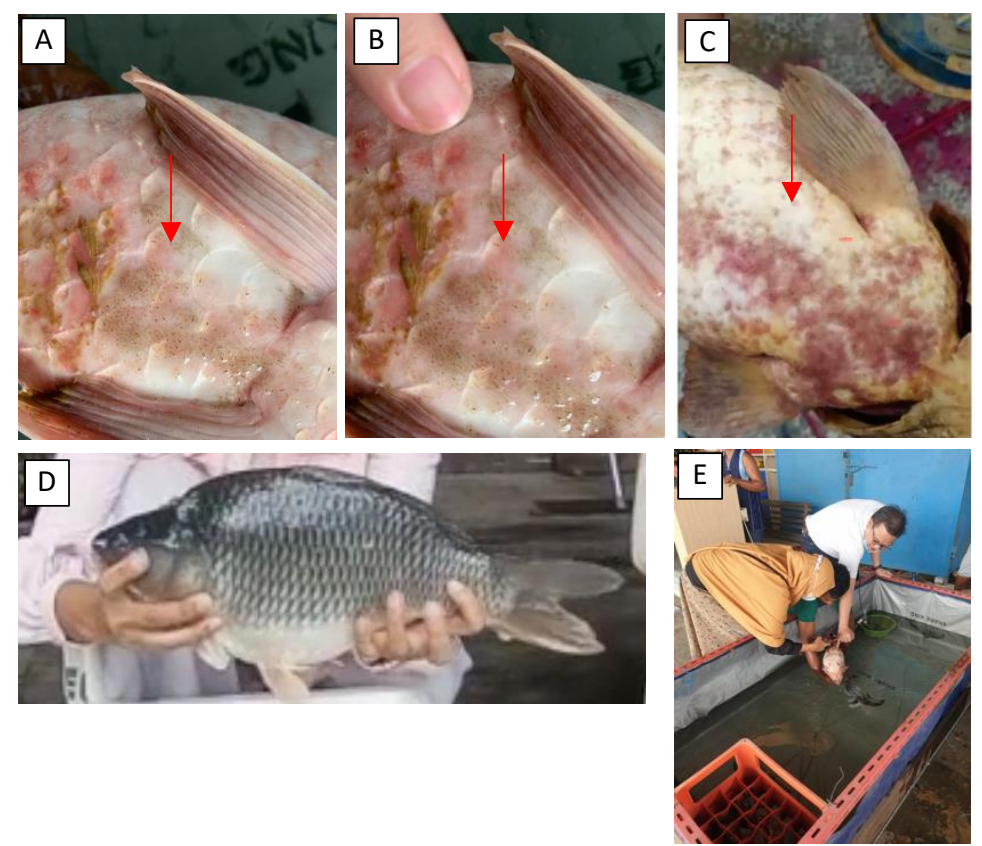

Figure 10. (A), (B), and (C) goldfish infected by Argulus sp. (D) goldfish used for experiments, (D) pond for growing goldfish. 


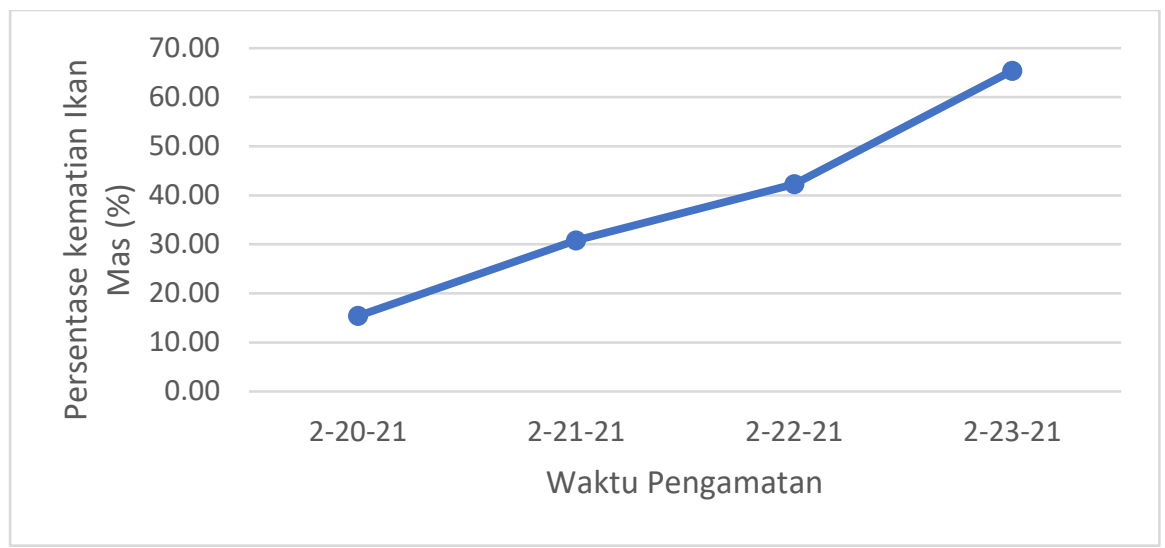

Figure 11. Cumulative mortality rate of goldfish in fish pond from 20th to 23rd of February 2021, before medication with extract.

Fish death at the beginning of infection of Argulus sp. reached 15.38\%, and the cumulative death kept increasing until $65.38 \%$ four days after infection (Figure 11). Hence, infection kept increasing, and dead fish had Argulus sticking to their body, with redness, wounds, and necrose (Figure 10).

\subsection{In vitro testing of antiparasitic activities}

The first stage of medication was performed by testing the effectiveness in SFE single extract and a concoction with BPE and ZZE against the Argulus sp. parasite in vitro. The results showed that single SFE (A2) in the in vitro test had the highest antiparasitic activities of up to 100\% and killed Argulus sp. in 240 minutes (Figure 12).

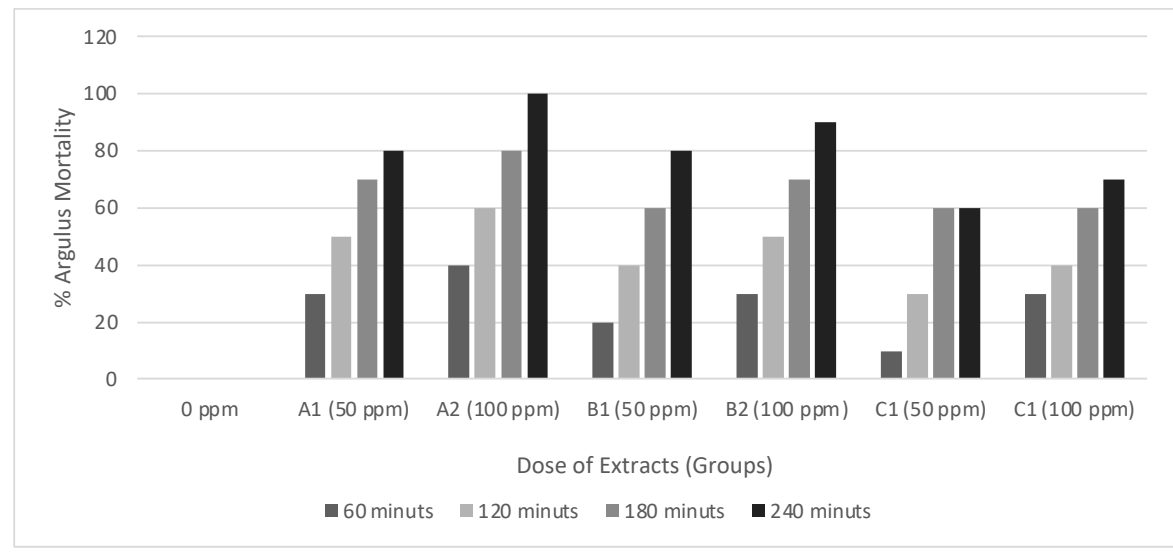

Figure 12. In vitro mortality of Argulus sp. treated with different concentrations of single and concoction extract of S. ferox, B. pandurata, and Z. zerumbet.

The efficiency level of extract on the Argulus sp. parasite in vitro was approximately $70-100 \%$ in 240 minutes. This result shows the suitability of using SFE (at $400 \mathrm{ppm}$ ), whereas 
the dose at $100 \mathrm{ppm}$ was capable of killing Argulus sp. at a rate of $100 \%$ (Table 1). Comprehensively, single and concoction extracts had an efficiency higher than 50\% in 180 and 240 minutes.

Table 1. (In vitro study) estimate of antiparasitic efficacy (\%) of S. ferox, B. pandurata, and Z. zerumbet extracts against Argulus.

\begin{tabular}{ccccc}
\hline \multirow{2}{*}{ Treatment } & \multicolumn{4}{c}{ Observation time (minutes) } \\
\cline { 2 - 5 } & 60 & 120 & 180 & 240 \\
\hline A1 & 30 & 50 & $70 \%$ & $80 \%$ \\
A2 & 40 & $60 \%$ & $80 \%$ & $100 \%$ \\
B1 & 20 & $40 \%$ & $60 \%$ & $80 \%$ \\
B2 & 30 & $50 \%$ & $70 \%$ & $90 \%$ \\
C1 & 10 & $30 \%$ & $60 \%$ & $60 \%$ \\
C2 & 30 & $40 \%$ & $60 \%$ & $70 \%$ \\
\hline
\end{tabular}

Some plant extracts were antibacterial and capable of killing Argulus sp. parasites. Ekanem et al. [18] conducted in vitro testing on a rough extract of Mucuna pruriens and Carica papaya on a protozoa parasite. Extracts of Mucuna and Papaya oil had an effectiveness of 35\% and $60 \%$, respectively, after 3 hours, whereas $100 \%$ parasite death was observed at 6 hours when using 100 and $150 \mathrm{ppm}$. To determine the anthelmintic activities of a Henna herbal extract, Ayderke and Amedmado also showed the in vitro efficacy on an ectoparasite [38]. Similarly, Mehlhorn et al. [39] evaluated the ovicidal effect in a product (Wash Away Louse), namely neem seed extract against nits on the body and head at different time intervals, and showed that a 5-minute incubation time was effective for preventing any incubation. Meanwhile, approximately $4 \%$ and $76 \%$ of larva in the control without treatment hatched in sequential order.

\subsection{Testing for antiparasitic efficiency of SFE, BPE, ZZE in vivo in goldfish}

In vivo medication testing demonstrated that soaking with single extract and a concoction of SFE, BPE and ZZE extracts at different concentrations resulted in a significant decrease in goldfish infection. Table 2 shows the highest decrease of Argulus sp. infection in medication using SFE at 100 ppm of up to $81.33 \%$ (S.D. $=3.21 \%$ ) and a significant difference from the control and other compositions $(\mathrm{P}<0.05)$. 
Table 2. (In vivo) concentration effect of extracts of BPE, SFE, and ZZE against Argulus sp. parasite on goldfish after 12 hours of treatment.

\begin{tabular}{cc}
\hline Treatment & Level of dead Argulus parasite (\%) \\
\hline K & $0 \pm 0.00^{\mathrm{a}}$ \\
A2 & $81.33 \pm 3.21^{\mathrm{b}}$ \\
B2 & $75.67 \pm 6.03^{\mathrm{c}}$ \\
C2 & $71.00 \pm 1.00^{\mathrm{c}}$ \\
\hline
\end{tabular}

Some plant extracts were antibacterial and antiparasitic. In vivo testing showed that Azadirachtin resulted in a significant reduction in the Argulus burden of goldfish [22]. The in vivo use of two isolated compounds - arctigenin and arctiin - against gill parasites was found to be efficacious at 0.62 and $3.55 \mathrm{mgL}^{-1}$, with $50 \%$ and $100 \%$ efficacies at $10.0 \mathrm{mg} \mathrm{L}^{-1}$, respectively [19]. Similarly, in vivo testing of Nerium oleander extract in the destruction of Argulus foliaceus and Lernaea cyprinacea in ornamental fish [40].

Table 3. Effect of time interval in application of extracts from BPE, SFE, and ZZE against Argulus sp. parasite on goldfish (in vivo).

\begin{tabular}{ccccccc}
\hline \multirow{2}{*}{ Treatment } & \multicolumn{5}{c}{ Average level of dead Argulus (\%) } \\
\cline { 2 - 7 } & 2 hours & 4 hours & 6 hours & 8 hours & 10 hours & 12 hours \\
\hline K & $0.00 \pm 0.00$ & $0.00 \pm 0.00$ & $0.00 \pm 0.00$ & $0.00 \pm 0.00$ & $0.00 \pm 0.00$ & $0.00 \pm 0.00$ \\
A2 & $1.33 \pm 1.15$ & $5.67 \pm 1.15$ & $9.67 \pm 0.58$ & $15.33 \pm 0.58$ & $20.33 \pm 1.53$ & $29.00 \pm 1.00$ \\
B2 & $3.67 \pm 1.15$ & $4.67 \pm 0.58$ & $11.33 \pm 1.53$ & $14.33 \pm 1.15$ & $18.67 \pm 1.53$ & $23.00 \pm 1.00$ \\
C2 & $3.67 \pm 1.15$ & $5.00 \pm 1.00$ & $10.33 \pm 0.58$ & $12.67 \pm 0.58$ & $18.00 \pm 1.00$ & $21.33 \pm 1.53$ \\
\hline
\end{tabular}

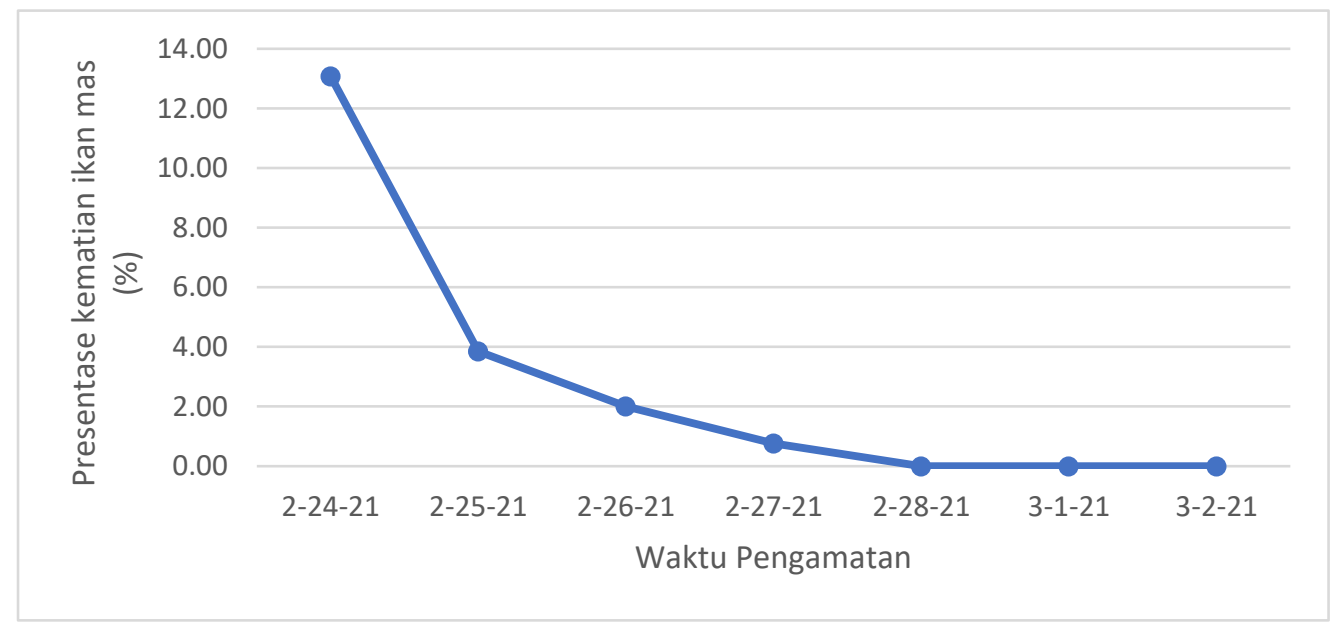


Figure 13. Mortality percentage of goldfish in fish pond from $24^{\text {th }}$ of February 2021 to $2^{\text {nd }}$ of March 2021, before medication with extracts of SFE, BPE, and ZZE.

\section{Discussion}

Our results demonstrate that for in vitro testing, the death rate of Argulus sp. was more rapid compared with the in vivo tests. This difference was caused by Argulus being vulnerable to the medication with the in vitro extract because it was removed from the host. Meanwhile, for in vivo medication, Argulus was protected by the host's scales and fins, in general agreement with in vivo and in vitro testing for all types of medication for fish [41]. In vitro tests are feasible for assessing the intrinsic activities of a substance, but it is currently not impossible to replicate complex in vivo regulation [41].

Viewed from the exposure time of Argulus sp. with the extract, the amount of dead Argulus sp., as shown in Table 3, reached $29.00 \% \pm 1.00$. Regarding the Argulus infective dose in fish, 15-20 Argulus can cause moderate disease, leading to a low level of hemorrhage in some goldfish $^{22}$. The capability of killing Argulus in extracts of SFE, BPE, and ZZE was excellent (71.00-80.33\% in in vivo testing after 12 hours of medication). Testing with the Azadirachtin solution extract with the soaking method led to around 9.33-53.33\% killing in vivo following 12 hours of medication.

The single S. ferox extract and concoction with BPE and ZZE had solasodine as a part of the steroidal glycoalkaloid. Solasodine can prevent food absorption and disturb growth in most insects [27]. Moretti et al. [42] successfully isolated the natural steroid compound 3bamino-22,26-epiminocholest-5-ene (sarachin) from an extract of Saraca punctate leaves, and this compound had killing activity against the malaria parasite — plasmodium falciparum — due to a series of amino steroids with side chains similar to sarachin. This explanation also applies to the antiparasitic activities of single SFE and the concoction with BPE and ZZE.

Solasodine is the most active derivative that might contribute to the antiparasitic activities. The advantage of using the hydrophobic steroid unit is its membrane permeability, opening a path for the biologically active hybrid molecule [44]. On that basis, the synthesized steroid and concoction from the hydrophobic steroid group and hydrophobic group (ferrocenylmethylamino, N-alkil-pridinium groups) [43] were responsible for the compounds' antimicrobial activities. The antiparasitic activity of the higher concoction extract composition demonstrates its increased antiparasitic capability. The solasodine concentrations in the single SFE and concoction with SFE and BPE as well as SFE and ZZE were 665 ppm, 485 ppm, and 295 ppm, respectively. 
In sum, the S. ferox extract with solasodine, in the single extract and concoction, can be used for killing Argulus sp. parasites, whereas the concoction extract had a better antiparasitic effect.

\section{Material and Methods}

\subsection{Experimental Fish}

Fish used in this research were goldfish (Cyprinus carpio) with a weight of $4-5 \mathrm{~kg}$ obtained from the Mahkota fish pond, Sungai Kapih Street, Sambutan District, Samarinda City, East Kalimantan. Meanwhile, 36 fish severely infected by Argulus were used and were marked with redness and Argulus found throughout the entire fish body, including the caudal, pectoral, and abdominal fins, at a high percentage.

An experiment was conducted on the $24^{\text {th }}$ of February 2021 during one death case caused by the attack of Argulus.

\subsection{Plant extracts and Extraction process}

The third extraction process of material was conducted in stages that were almost the same as the method of Hardi et al. [28,29], in which BPE, ZZE, and SFE were washed until clean with flowing water, cut into small pieces with a thickness of $0.5 \mathrm{~cm}$ using a cutting machine, and dried with an oven $\left(40-45^{\circ} \mathrm{C}\right)$ for 24 hours for temu kunci and lempuyang and 48 hours for sour eggplant. After that, the dried ingredients were mashed with a blender, and the simplicia slices were soaked in $96 \%$ ethanol liquid, filtered with filter paper, and evaporated using an evaporator with scale-up. The extracts were transferred into a sterile Becker glass, stored in an oven for 24 hours to obtain an extract viscosity of 10-11, and then maintained at $4{ }^{\circ} \mathrm{C}$ before use. The extracts used in this research had two compositions, using the best concentration of three extracts from previous research [28-36].

The Argulus medication experiment in goldfish used three different extract compositions, namely:

Composition A : Solanum ferox (SFE 400 ppm) and Zingiber zerumbet (ZZE 200 ppm) extracts, ratio 1:1.

Composition B : SFE (400 ppm) and Boesenbergia pandurata (BPE 900 ppm) extracts with ratio $1: 1$.

Composition C : single SFE (400 ppm) extract.

\subsection{Solasodine content analysis}


HPLC was used for determining the solasodine content in the sour eggplant extract and its derivative product. The condition/system of analysis for extract sample, extracts composition A, B, C using HPLC was as follows:

$\begin{array}{ll}\text { Motion Phase } & : \text { Acetonitrile (30:70) } 0.5 \% \text { phosphoric acid } \\ \text { Injection Volume } & : 10 \mu \mathrm{L} \\ \text { Column } & : \text { ShimPack GIST C18 } \\ \text { Column Oven Temperature } & : 25^{\circ} \mathrm{C} \\ \text { Solvent Flow Rate } & : 1 \mathrm{~mL} / \text { minute } \\ \text { Detector } & : \text { PDA } \\ \text { Analysis Time } & : 10 \text { minutes }\end{array}$

Solasodine contents were determined at the Advanced Characterization Laboratory of Cibinong - Integrated Bioproduct Laboratory, National Institute of Science. Examinations of solasodine bioactive compounds were performed in S. Ferox extract and Compositions A (SFE and ZZE), B (SFE and BPE), and C (SFE) from the extract used in this research. Solasodine can be used as one of the identifiers for determining plant identity in Solanaceae and its extract. Content in plant extract from the Solanaceae family on its derivative products can be approached with the solasodine tracking method.

\subsection{In vitro testing of parasitic activities from plant extracts}

In vitro analyses were conducted following the procedure of Ekanem et al. [18]. Argulus sp. were removed from the infected fish carefully with plastic forceps and placed into a petri dish, and moving active parasites were chosen with an ose needle. Ten living, active parasites were moved manually into a petri dish containing $20 \mathrm{ml}$ of liquid extract compositions $\mathrm{A}, \mathrm{B}$, and $\mathrm{C}$ at different concentrations. Every 60 minutes, the number of dead parasites was calculated until 240 minutes. Parasite death was determined when Argulus sp. did not show any motion after being touched with the ose needle.

This in vitro research used seven treatments, and every treatment was repeated three times as follows:

For the control, Argulus was soaked with freshwater without adding extract/0 ppm.

A1, Argulus was soaked with composition A at $50 \mathrm{ppm}$.

A2, Argulus was soaked with composition A at $100 \mathrm{ppm}$.

B1, Argulus was soaked with composition B at $50 \mathrm{ppm}$.

B2, Argulus was soaked with composition B at 100 ppm. 
$\mathrm{C} 1$, Argulus was soaked with composition $\mathrm{C}$ at $50 \mathrm{ppm}$.

C2, Argulus was soaked with composition C at 100 ppm.

The antiparasitic efficacy of each group was calculated using the equation of Wang et al. [19]: $\mathrm{AE}=(\mathrm{B}-\mathrm{T}) / \mathrm{B} X(100 \%)$

in which $\mathrm{AE}=$ antiparasitic efficacy, $\mathrm{B}$ is the mean number of surviving Argulus in the control, and $\mathrm{T}$ is the mean number of surviving Argulus in the treatment.

\subsection{In vivo testing of parasitic activities from plant extracts on goldfish}

This stage involved medication using four treatments, and every treatment was repeated three times. The In vitro testing showed that the single extract and concoction with three extracts had antiparasitic capabilities against Argulus, but 100 ppm had better antiparasitic activities, compared with $50 \mathrm{ppm}$; hence, the in vivo tests used four treatments, as follows: $\mathrm{K}$ treatment, fish soaked with freshwater without adding extract/0 ppm.

A2 treatment, fish soaked with composition 1 at $100 \mathrm{ppm}$.

B2 treatment, fish soaked with composition 2 at $100 \mathrm{ppm}$.

C2 treatment, fish soaked with composition 3 at 100 ppm.

Three goldfish (for every repetition) weighing 4-5 kg, infected by Argulus, were soaked in extract liquids of different compositions for 12 hours, and the number of Argulus released from goldfish was calculated every 2 hours (2, 4, 6, 8, 10, and 12 hours).

After medication for 12 hours, fish were transferred back into the container to evaluate the survival of goldfish for seven days (from the $24^{\text {th }}$ of February 2021 to the $2^{\text {nd }}$ of March 2021). Data regarding fish survival after medication were obtained every day.

\subsection{Statistical analysis}

The collected data were analyzed using the statistical package SPSS version 16.

\section{Conclusion}

In this research, a single extract of S. ferox and a concoction with SFE and BPE as well as SFE and ZZE were used to identify the antiparasitic effect against Argulus sp. infecting goldfish. The inhibitive traits in the test results were affected by content and synergy, observed in most of the concoction examined, in which the SFE and concoction with BPE and ZZE. In practice, plant extracts concoctions have the best performance as antiparasitic in infected fish and this natural plant is effective in goldfish cultivation without side effects for curative medication and/or large-scale prevention and treatment. 
Esti Handayani Hardi ${ }^{1,2}$, Rudi Agung Nugroho ${ }^{2,3}$, Irawan Wijaya Kusuma ${ }^{4}$, Gina Saptiani ${ }^{1,2}$, Agustina $^{1}$, Abinawanto ${ }^{5}$, Yushinta Fujaya ${ }^{6}$, Bambang murtiyoso ${ }^{7}$, Tjahjo Winanto ${ }^{8}$, Nurhidayat ${ }^{9}$

\section{Author Contributions:}

Conceptualization, E.H.H ; R.A. N; Methodology, E. H. H, R.A.N, Y.F, I.W.K, and G.S; Formal Analysis, E.H.H, and R.A.N; Investigation, E.H.H, M.A, A.A, A.A, B.M, T. W, N.N, and A.L.; Resources, E.H.H and R.A.N; Writing-Original Draft Preparation, E.H.H and R.A.N; Writing-Review \& Editing, E.H.H, I. W. K, and R.A.N; Supervision, E.H.H and R.A.N; Project Administration A.A and Y.F. All authors have read and agreed to the published version of the manuscript.

Funding: This research received funding from Indonesian Education Scholarship (LPDP) year 2021. No Contract. 116/LPDP/2019.

Institutional Review Board Statement: Not applicable.

Informed Consent Statement: Not applicable.

Data Availability Statement: Data available on request.

Acknowledgments: All of the writers and researchers would like to express their gratitude to LPDP for providing the funds required to develop the natural fish drugs complete. In addition, they offer special thanks to students from the faculty of Fisheries and Marine Sciences, Mulawarman University, for their support and efforts in conducting this research.

Conflicts of Interest: The authors declare no conflict of interest.

Sample Availability: Samples of the compounds are available on request from the authors.

\section{References}

1. Kipp RM, Larson J, Fusaro A, Makled TH, Benson AJ. [Internet] 2014. Argulus japonicus. USGS Nonindigenous Aquatic Species Database. [Cited 13 November 2013] Available at: http://nas.er.usgs.gov/queries/FactSheet.aspx?speciesID=166.

2. Al Darwesh, A.A.; Al Shabbani, M.A.A.; Faris, B.H. Diagnostic and pathological study of Argulus japonicasin goldfish (Carassius auratus). G.J.B.B. 2014, 3 (4), 384-387.

3. Steckler N, Yanong RPE. [Internet]. 2012. Argulus (fish louse) infections in fish. UF/IFAS Fisheries and Aquatic Sciences. [Cited 10 November 2013]. Available at http://edis.ifas.ufl.edu/fa184

4. Noga. 2000. Fish Diseases ; Diagnosis and Treatment. Iowa State Press. A Blackwell. United State pp. 85-90.

5. Kabata, Z. 1985. Parasites and diseases of fish cultured in the tropics. Taylor \& Francis, London and Philadelphia, PA.

6. Alom, M.Z.; Yasmin, M.S.; Rahman, M.A.; Khan, S. Status, occurrence, intensity and impact of Argulosis in different brood stock ponds. MOJ Eco Environ Sci., 2019, 4(5), $225-229$. 
7. Noaman V, Chelongar Y, Shahmoradi A. 2010. The first record of Argulus foliacesus (Crustacea: Branchiura) infestation on lionhead goldfish (Carassius auratus) in Iran. Iran J Parasitol 5:71-76.

8. Lamarre, E., and P.A. Cochran. 1992. Lack of host species selection by the exotic parasitic crustacean Argulus japonicus. Journal of Freshwater Ecology 7(1):77-80.

9. Dewi, R.R.; Siallagan,W.; Suryanto, D. The efficacy of sodium chloride application in the control of fish lice (Argulus sp) infection on tilapia (Oreochromis niloticus). Acta Aquatica: Aquatic Sciences Journal, 2018, 5(1), 4-7.

10. Pandey AK, Nagpure NS, Trivedi SP, Kumar R, Kushwaha B. 2011. Profenofos Induced DNA Damage In Freshwater Fish, Channa punctatus (Bloch) Using Alkaline Single Cell Gel Electrophoresis. Mutation Research 726:209-214. www.elsevier.com/locate/gentox/ Tanggal Akses 2 Mei 2012.

11. Tona L, Kambu K, Ngimbi N, Climanga K, Vlietinck AJ (1998) Antiamoebic and phytochemical screening of some Congolese medicinal plants. J Ethnopharmacol 61:57-65

12. Willcox ML, Bodeker G (2000) Plant-based malaria control: research initiative on traditional antimalaria methods. Parasitol Today 16:220-221

13. Asres, K.; Bucar, F.; Knauder, E.; Yardley, V.; Kendrick, H.; Croft, S.L. In vitro antiprotozoal activity of extract and compounds from the stem bark of Combretum molle. Phytother Res., 2001, 15, 613-617.

14. Satrija F, Retnani EB, Ridwan Y, Tiuria R (2001) Potential use of herbal anthelmintics as alternative antiparasitic drugs for small holder farms in developing countries. In: Livestock community and environment. Proceedings of the 10th Conference of the Association of Institutions for Tropical Veterinary Medicine, Denmark

15. Ijah UJ, Oyebanji FO (2003) Effects of tannins and polyphenols of some medical plants on bacterial agents of urinary tract infections. Global J Pure Appl Sci 9:193-198

16. Madsen HCK, Buchmann K, Mellergaard S (2000) Treatment of trichodiniasis in eel (Anguilla anguilla) regarded in recirculation systems in Denmark: alternatives to formaldehyde. Aquaculture 186:221-231

17. Buchmann, K.; Jensen, P.B.; Kruse, K.D. Effects of sodium percarbonate and garlic extract on Ichthyophthirius multifiliis theronts and tomocysts: in vitro experiments. $\mathrm{N}$ Am J Aquac., 2003, 65, 21-24.

18. Ekanem, A.P.; Obiekezie, A.; Kloas, W.; Knopf, K. Effects of crude extracts of Mucuna pruriens (Fabaceae) and Carica papaya (Caricaceae) against the protozoan fish parasite Ichthyophthirius multifiliis. Parasitol Res., 2004, 92:361-366

19. Wang LD, Guo DA, Yuan L, He QH, Hu YQ, Tu PF, et al. Antifungal effect of three natural products on the genetic substance of Saccharomyces cerevisiae GL7 and Prototheca wickerhamii. Yao Xue Xue Bao 2000; 35(11): 860-863

20. Chang, W.; Li Y.; Zhang, M.; Zheng, S.; Li Y.; Lou H. Solasodine-3-O- $\beta$-dglucopyranoside kills Candida albicans by disrupting the intracellular vacuole. Food and Chemical Toxicology, 2017, 106, 139-146.

21. Mandalakis,M.; Anastasiou, T.I.; Martou, N.; Keisaris, S.; Greveniotis, V.; Katharios, P.; Lazari, D.; Krigas, N.; Antonopoulou, E. Antibacterial Effects of Essential Oils of Seven Medicinal-Aromatic Plants against the Fish Pathogen Aeromonas veronii bv. sobria: To Blend or Not to Blend?. Molecules 2021, 26, 2731. https://doi.org/10.3390/ molecules26092731. 
22. Kumar P, Sharma B, Bakshi N. 2009. Biological activity of alkaloids from Solanum dulcamara L. Nat Prod Res 23: 719-23.

23. Bibon, M.B. Antibacterial in-vitro evaluation of phenotypically screened solasodine from Solanum nigrum Linn. against enterohemorrhagic Escherichia coli (0157:H7). International Journal of Scientific Research in Research Paper, 2021, 7, 43-48..

24. Jubair N, Rajagopal M, Chinnappan S, Abdullah NB, Fatima A. 2021. Review on the Antibacterial mechanism of plant-derived compounds against multidrug-resistant bacteria (MDR). Evidence-Based Complementary and Alternative Medicine 2021: 130 .

25. Shen K-H, Hung JH, Chang CW, Weng YT, Wu MJ, Chen SP. 2017. Solasodine inhibits invasion of human lung cancer cell through downregulation of miR-21 and MMPs expression. Chemico-Biological Interactions 268: 129-135.

26. Xu X-H, Zhang L-L, Wu G-S, Chen X, Li T, Chen X, Wang Y-T, Lu J-J. 2017. Solasodine induces apoptosis, affects autophagy, and attenuates metastasis in ovarian cancer cells. Planta Med 83: 254-260.

27. Krieg R, Esther Jortzik2, Alice-Anne Goetz3, Ste' phanie Blandin3, Sergio Wittlin4,5, Mourad Elhabiri6, Mahsa Rahbari2, Selbi Nuryyeva6,7, Kerstin Voigt8, Hans-Martin Dahse8, Axel Brakhage8, Svenja Beckmann9, Thomas Quack9, Christoph G. Grevelding9, Anthony B. Pinkerton10,11, Bruno Scho necker12, Jeremy Burrows13, Elisabeth Davioud-Charvet6, Stefan Rahlfs2 \& Katja Becker. 2016. Arylmethylamino steroids as antiparasitic agents. Nature Communication. 8:14478 | DOI: 10.1038/ncomms14478 | www.nature.com/naturecommunications

28. Hardi, E.H.; Saptiani, G.; Kusuma, I, W.; Suwinarti, W.; Nugroho, R. A. Antibacterial activities of some Borneo plant extracts against pathogenic bacteria of Aeromonas hydrophila and Pseudomonas sp. AACL Bioflux, 2016a, 9(3), 638-646.

29. Hardi, E.H.; Kusuma, I.W.; Suwinarti, W.; Agustina; Nugroho, R.A. Antibacterial activity of Boesenbergia pandurata, Zingiber zerumbet and Solanum ferox extracts against Aeromonas hydrophila and Pseudomonas sp. Nusantara Biosci, 2016b, 8(1), 18-21. 10.13057/nusbiosci/n080105

30. Hardi EH, et al.: Borneo herbal plant extracts as a natural medication for prophylaxis and treatment of Aeromonas hydrophila and Pseudomonas fluorescens infection in tilapia (Oreochromis niloticus). F1000Res. 2018;7. 30984371 10.12688/f1000research.16902.2 PMC6439779

31. Hardi EH, et al.: Inhibition of fish bacteria pathogen in tilapia using a concoction three of Borneo plant extracts. In: IOP Conference Series. Earth and Environmental Science: IOP Publishing;2018.

32. Hardi EH, et al.: Uji in vitro Gabungan Ekstrak Boesenbergia pandurata, Solanum ferox, Zingimber zerumbet terhadap Bakteri Patogen pada Ikan Nila. Jurnal Veteriner. 2018;19(1):35-44. 10.19087/jveteriner.2018.19.1.35

33. Hardi EH, et al.: Boesenbergia pandurata application in goldfish (Cyprinus carpio) feed to enhance fish growth, immunity, and resistance to bacterial infection. OSF. 2021. 10.17605/OSF.IO/827EN

34. Hardi EH, et al.: Immunomodulatory and antibacterial effects of Boesenbergia pandurata, Solanum ferox, and Zingiber zerumbet on tilapia, Oreochromis niloticus. AACL Bioflux. 2017a;10(2):182-190.

35. Hardi EH, et al.: Simultaneous Administration of Boesenbergia pandurata Extract and Vaccination to Stimulate Immune Response in Tilapia, Oreochromis niloticus. Pak J Biol Sci. 2019;22(9):419-426. 31930872 10.3923/pjbs.2019.419.426 
36. Hardi EH, N R, Kusuma IW, et al.: Immunomodulatory effect and disease resistance from three Borneo plant extracts to Aeromonas hydrophila and Pseudomonas fluorescens in tilapia, Oreochromis niloticus. Aquacultura Indonesiana. 2019;20(1):41-47. 10.21534/ai.v20i1.135

37. Y1ldiz KKA, Kumantas A. 2002. Argulus foliaceus infection in a goldfish (Carassius auratus). Isr J Vet Med 57:118-120.

38. Eguale, T., Gebreyes, W.A., Asrat, D. et al. Non-typhoidal Salmonella serotypes, antimicrobial resistance and co-infection with parasites among patients with diarrhea and other gastrointestinal complaints in Addis Ababa, Ethiopia. BMC Infect Dis 15, 497 (2015). https://doi.org/10.1186/s12879-015-1235-y

39. Mehlhorn H, Abdel-Ghaffar F, Al-Rasheid KA, Schmidt J, Semmler M. Ovicidal effects of a neem seed extract preparation on eggs of body and head lice. Parasitol Res. 2011 Nov;109(5):1299-302. doi: 10.1007/s00436-011-2374-8. Epub 2011 Apr 12. PMID: 21484346.

40. Sundus Wavi Al-zayyadi. 2019. Study of the effect of Nerium oleander extract in the destruction of Argulus foliaceus and Lernaea cyprinacea in ornamental fish International journal of Research in Pharmaceutical Sciences. 10(4): 3073-3077.

41. Kirby 1996 / Natalie Steckler and Roy P. E. Yanong. 2017. Argulus (Fish Louse) Infections in Fish. U.S. Department of Agriculture, UF/IFAS Extension Service, University of Florida, IFAS, Florida A \& M University Cooperative Extension Program, and Boards of County Commissioners Cooperating. Nick T. Place, dean for UF/IFAS Extension. Pp 4

42. Moretti, C. et al. A novel antiprotozoal aminosteroid from Saracha punctata. J. Nat. Prod. 61, 1390-1393 (1998).

43. Shafir A, van As JG. 2009. Laying, development, and hatching of eggs of the fish ectoparasite Argulus japonicus (Crustacea, Branchiura). J Zool 210:401-413.

44. Thongchai W, Liawruangrath B, Liawluangrath S, Saysin S. 2011. High Performance Liquid Chromatographic determination of solasodine in solanum species. Asian Journal of Chemistry 23: 2407-2410.

45. Khandani SK, Mehrabani M, Sharififar F, Pardakhty A, Pournamdari M, Pakravanan M. 2019. Development and validation of an RP-HPLC method for determination of solasodine, a steroidal alkaloid. J Young Pharm 11: 21-25.

46. Singh P, Singh P, Singh MP. 2019. Quantitative estimation of steroidal drug solasodine in wild species of Solanum by reversedphase HPLC method. Journal of Pharmacognosy and Phytochemistry 8: 920-926

47. Hardi EH, Saptiani G, Nugroho RA, fadlul Rahman, Sulistyawati, Widyaningsih Rahayu, Ali Supriansyah, Irawan Wijaya Kusuma. Boesenbergia pandurata application in Goldfish (Cyprinus carpio) Feed to Enhancing Fish Growth, Immunity System, and Resistance to Bacterial Infection [version 2; peer review: 2 approved]. F1000Research 2021, 10:766 (https://doi.org/10.12688/f1000research.52889.2)

48. Hardi EH, Nugroho RA, Rostika R, Mardliyaha CM, Sukarti K, Rahayu W, Supriansyah A, Saptiani G. Synbiotic application to enhance growth, immune system, and disease resistance toward bacterial infection in catfish (Clarias gariepinus), Aquaculture, 549, 2022, 737794, ISSN 0044-8486, 